\title{
EPIDEMIOLOGICAL PROFILE OF MALARIA IN THE STATE OF TOCANTINS, BRAZIL, FROM 2003 TO 2008*
}

Éldi Vendrame PARISE(1), Gessi Carvalho de ARAÚJO(2), José Gerley Diaz CASTRO(3) \& Fernando Pedroso BERDARRAIN(4)

\begin{abstract}
SUMMARY
This study describes the epidemiological profile of malaria in the State of Tocantins, in the period 2003-2008, investigates the association between the frequency of malaria and population growth, classifies the cases by 'autochthonous' and 'imported', reports the indices of the disease and analyses the distribution of the cases by Plasmodium species, age and gender. The retrospective study was based on secondary data, stored in SIVEP-malaria and analyzed using the software Epi-Info 3.5.1. and Bioestat 5.0. 19,004 samples were investigated for malaria, $19 \%$ of them were positive, $73.32 \%$ with Plasmodium vivax, $21.80 \%$ with Plasmodium falciparum, 4.79\% with mixed infections and only $0.08 \%$ with Plasmodium malariae. Male individuals accounted for $76.95 \%$ and predominated in all years and age groups, especially in the 15 to 49 years old group. From the overall cases, $34.27 \%$ were autochthonous and $65.73 \%$ were imported $\left(\chi^{2}=356.8, p=0.0001\right)$. The frequency of malaria decreased significantly during the entire series $(\mathrm{rp}=0.96, p=0.002)$ and the number of municipalities with autochthonous transmission also diminished. It was found that malaria is predominantly imported, related to land activities, which confirms the need for effective measures to maintain vigilance throughout the state and enhance educational activities in order to guide the population towards early treatment-seeking.
\end{abstract}

KEYWORDS: Tocantins Malaria; Epidemiology; Plasmodium; Transmission.

\section{INTRODUCTION}

Human malaria is a fast-evolving parasitic disease that is still a serious problem to public health. In addition to the fact that $40 \%$ of the world population living in tropical and subtropical areas is at risk of contracting the disease, it is estimated that between 300 and 500 million new cases per year will appear, causing 1.5 to 2.7 million deaths annually, striking mostly children under five years old ${ }^{18,23}$.

The infection is caused by a unicellular protozoan of the genus Plasmodium and each species has different characteristics to the disease. In Brazil, the most frequent species that cause infection in humans are: $P$. vivax, which accounted for $83.7 \%$ of registered cases, $P$. falciparum, by $16.3 \%$ and $P$. malariae (rarely observed ${ }^{26}$. However, studies conducted by ARRUDA et $a l .^{2}$ revealed a discrepancy between the prevalence of antibodies against $P$. malariae and the malaria cases officially reported. According to the authors, the low incidence of reports on this species is due to the thick smear method, the official technique for the diagnosis of malaria in Brazil, which does not allow the evaluation of morphological difference of erythrocytes infected with $P$. vivax and $P$. malariae, and this can lead to a misidentification of the species, underestimating the true incidence of the latter.

The main form of malaria transmission is through the bite of an infected female Anopheles mosquito. It usually occurs in populations living in poor housing and labor conditions, in a context of disordered land occupation, mineral exploration, agrarian colonization, settlement areas and intense migration from rural areas to the outskirts of the $\operatorname{cities}^{33}$. The quality and the extension of protection and healthcare measures towards the exposed populations has positively influenced the control of the disease ${ }^{20}$, but the difficulties faced to reduce economic and social risk factors in the Amazon region hamper the elimination of the disease ${ }^{26}$.

Regarding the prophylaxis, there is no available vaccine that protects against malaria. To be more protected, people need to be informed about the risks of contracting the disease, set appropriate security measures and still be aware that all prevention methods can fail. If this occurs, early diagnosis and appropriate treatment are today the main foundations for the control of the disease ${ }^{24}$.

In the American continent $36.5 \%$ of people live in areas propitious to the transmission of the disease ${ }^{17}$. In Latin America, countries that share the Amazon rainforest (Bolivia, Colombia, Ecuador, Peru, Venezuela, Brazil, French Guyana, Guyana and Suriname), suffered the greatest impact of the problem in 2004, with $91 \%$ of malaria cases and $79 \%$ of deaths attributed to malaria. Brazil counted $52.27 \%$ of the total cases, followed by Colombia and Peru ${ }^{27}$.

*Part of the Master Thesis of E.V. Parise, presented at UFT, Palmas, TO, Brazil.

Financial support: Science and Technology Office (SECT) of Tocantins, Brazil.

(1) Health and Surveillance authority, Municipal Health Office of Palmas, TO, Brazil.

(2) Coordination of Professional Master in Health Science, Federal University of Tocantins, Palmas, TO, Brazil.

(3) Coordination of Nursing and Nutrition, Federal University of Tocantins, Palmas, TO, Brazil.

(4) Coordination of Health Surveillance Information, Health Office of Tocantins, Palmas, TO, Brazil.

Correspondence to: Éldi Vendrame Parise, 106 Sul, Alameda 14, lote 06, 77020-062 Palmas, TO, Brasil. Tel. +55.63 30262521/3218-5106. E-mail: eldiparise@ gmail.com 


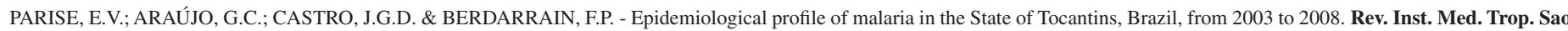
Paulo, 53(3): 141-7, 2011

In the Brazilian area, $99.8 \%$ of malaria cases are found in the Amazon region which comprises the states of Acre, Amapá, Amazonas, Maranhão, Mato Grosso, Pará, Rondônia, Roraima and Tocantins ${ }^{24}$. The region has geographical and ecological characteristics highly favorable for the interaction of the Plasmodium and Anopheles mosquitoes, which, linked to socio-cultural, economic and political factors depending on man, create different levels of endemic transmission ${ }^{20}$.

Tocantins is located in the southeast of Northern Brazil and borders in the South with the State of Goiás, in the North with Maranhão and Pará, in the East with Maranhão, Piauí and Bahia, and in the West with Mato Grosso and Pará ${ }^{15}$. In spite of being part of the Amazon Region, Tocantins is now considered a non-endemic area with malaria transmission risk ${ }^{23}$ and presents favorable climate and environmental characteristics for the development of the vector.

In accordance with this situation, it is of fundamental importance to have an annual assessment of malaria indices in this tropical region, in order to know the epidemiology of the disease and collaborate with agencies responsible for its control. In this sense, the objective of this study was to make a survey of malaria cases reported in the state of Tocantins in the period 2003-2008 in order to quantify the risk of disease transmission, check the distribution of cases according to 'autochthonous' and 'imported' classification, describe the frequency and percentage of cases by Plasmodium species, as well as knowing the most prevalent age and gender in sufferers of the disease.

\section{MATERIALS AND METHODS}

The study was conducted in the state of Tocantins, whose land area covers $277,620,914 \mathrm{~km}^{2}$ with a population of $1,280,509$ inhabitants and a density of 4.5 inhabitants per square kilometer ${ }^{15}$.

The research refers to a retrospective study of epidemiological profile, based on secondary data, in which a survey was conducted with the description of all malaria cases reported in the Tocantins State, in the period 2003-2008. The data were obtained from the Malaria Epidemiological Surveillance System-Malaria (SIVEP-Malaria) of the Health Surveillance Office at the Ministry of Health, available online. Census data and population estimations of each year were obtained from the site of the Universal Healthcare System Database (DATASUS), from the source of the Brazilian Institute of Geography and Statistics (IBGE) ${ }^{15}$.

The study was based on the frequency and incidence of the disease, from the number of positive cases reported in the State, through active and passive search; the cases were classified according to the origin (autochthonous and imported); posted in accordance with Plasmodium species ( $P$. falciparum, $P$. vivax and $P$. falciparum $+P$. vivax) and the distribution of cases was done by age and gender.

The indicator used to calculate the risk of malaria transmission was the Annual Parasite Index (API), calculated from the number of positive slides of malaria in the year, divided by the population, multiplied by a thousand, according to ATANAKA-SANTOS et al. ${ }^{3}$ and CORREA \& ALVES $^{11}$. However, the Interagency Information Network for Health (RIPSA) ${ }^{29}$ emphasizes that this indicator has limitations, specifically with regards to the examined slides because they can show a new case, a recurrence or several slides of the same person. For this reason, the suggestion of DIAS ${ }^{13}$ was adopted and the number of new cases of the disease was used in the numerator instead of the overall number of positive slides, that is, only the samples collected by passive surveillance and active searching, avoiding duplicate cases.

From the results of the API, the state was classified into four levels: a) high risk (API greater than 49.9 cases per thousand inhabitants), b) medium risk (API between 10 and 49.9 cases per thousand inhabitants); c) low risk (API between 0.1 and 9.9 cases per thousand inhabitants) and d) no risk (zero API) ${ }^{23}$.

After the API, the Annual Blood Examination Rate (ABER), the Slide Positivity Rate (SPR), the Slide P. falciparum Rate (SPfR) and Slide $P$. vivax Rate (SPvR) were also analyzed, according to ATANAKASANTOS et al. $^{3}$ and SILVEIRA \& REZENDE ${ }^{33}$.

The variation of the reduction in recorded malaria cases was expressed by the percentage of difference between the number of positive cases from one period to another, like the procedures used by ALVES et al. ${ }^{1}$.

The average API for the period 2003-2008, calculated for the age group, was based on the sum of annual APIs from each age group divided by six (number of years studied), similar to the procedure used by ATANAKA-SANTOS et l. $^{4}$ and CHAVES \& RODRIGUES ${ }^{10}$.

The data were compiled in figures and tables for a better interpretation of the epidemiological scenario, and the statistical analysis was worked out using the software Epi Info version 3.5.1 and version 5.0 BioeStat. The Spearman Correlation $\left(\mathrm{r}_{\mathrm{s}}\right.$ ) was used to correlate population growth and positive cases and the Pearson Correlation $\left(\mathrm{r}_{\mathrm{p}}\right)$ was used to relate smears and positive slides. To compare the positive cases by Plasmodium species a Kruskal-Wallis $(\mathrm{H})$ test was made and the comparison between the genders was tested with the Mann-Whitney (U) test. Cases of autochthonous and imported malaria were compared by the Chi-square test, and all tests were performed considering a significance level of 5\%.

In accordance with the ethical standards for research involving human subjects contained in the resolution no. 196/96 of the National Board of Health, the research project was submitted to the Ethics Committee of the Federal University of Tocantins and was approved in plenary on June $10^{\text {th }} 2008$ under number 024/2008.

\section{RESULTS}

For the overall period of this study, 19,004 blood sample records were analyzed using the thick blood smear method, for the Plasmodium species, of which 3,610 (19\%) were positive. The number of positive cases of malaria has been decreasing every year according to the number of samples examined, and the Pearson correlation test showed a statistically significant reduction $\left(\mathrm{r}_{\mathrm{p}}=0.96, p=0.002\right)$. The frequency of positive cases showed no significant association with the demographic growth of the population $\left(\mathrm{r}_{\mathrm{s}}=-0.37, \mathrm{p}=0.46\right)$ and the percentage of variation in case reduction fluctuated between years interspersed $-15.65 \%$ to $-47.14 \%$, totaling, in the final series, a decrease of $86.37 \%$ (Table 1).

From the 3,610 cases reported during the study period, imported malaria was the most frequent, with $65.73 \%$ of cases $\left(\chi^{2}=356.8, p=\right.$ $0.0001)$. In 2003, from the 1,211 cases recorded, 691 were imported and 520 autochthonous, while in 2008, from 165 registered cases, 152 
Table 1

Annual population, blood samples examined for malaria, number and percentage of positive samples and positive variation recorded in Tocantins, in the period 2003 to 2008

\begin{tabular}{lccccc}
\hline \multirow{2}{*}{ Year } & Population & \multicolumn{3}{c}{ Blood samples } & \\
\cline { 3 - 5 } & & Examined & \multicolumn{2}{c}{ Positive } & \\
\cline { 3 - 5 } & & No. & No. & $\%$ & \\
\hline 2003 & $1,230,181$ & 4,743 & 1,211 & 25.53 & - \\
2004 & $1,262,644$ & 4,575 & 850 & 18.58 & -29.81 \\
2005 & $1,305,728$ & 3,757 & 717 & 19.08 & -15.65 \\
2006 & $1,332,441$ & 2,601 & 379 & 14.56 & -47.14 \\
2007 & $1,243,627$ & 2,029 & 288 & 14.21 & -24.01 \\
2008 & $1,280,509$ & 1,299 & 165 & 12.79 & -42.71 \\
\hline Total & & 19,004 & 3,610 & 19.00 & -86.37 \\
\hline
\end{tabular}

$\left(\mathrm{r}_{\mathrm{p}}=0.96 ; p=0.002\right),\left(\mathrm{r}_{\mathrm{s}}=-0.37 ; p=0.46\right)$

were imported and 13 autochthonous. There was a decrease of $78.00 \%$ of the imported cases and $97.50 \%$ of the autochthonous cases (Fig. 1). In the Chi-square test, a significant difference in the distribution of annual totals was detected between the two classifications $\left(\chi^{2}=158, p<0.05\right)$.

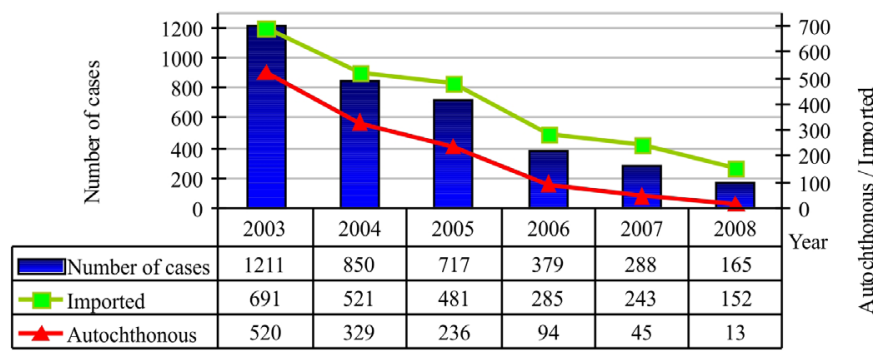

Fig. 1 - Annual distribution of malaria cases recorded in Tocantins, in the period 2003 to 2008 , according to the epidemiological classification. $\left(\chi^{2}=158 ; p<0.05\right)$

Due to this reduction in cases, the number of municipalities with transmission has also changed. In 2003 there were 42 cities $(30.22 \%)$ with autochthonous transmission and in 2008 there were only nine $(6.47 \%)$, a decrease of $78.57 \%$. With respect to imported cases, in 2003, 35 cities $(25.18 \%)$ reported the presence of imported malaria from other states or from abroad, whereas in 2008 only 25 districts $(17.98 \%)$ reported the presence of infected migrants. So, it's also a decrease of $28.57 \%$ of the counties with imported cases records.

Figure 2 illustrates the temporal distribution of cases, with decreasing tendencies in all three forms of malaria ( $P$. vivax, $P$. falciparum and mixed). P. vivax represented the majority with $73.32 \%$, and their frequency decreased continuously accumulating a decrease of $89.42 \%$. P. falciparum accounted for $21.80 \%$ of the infections with $78.12 \%$ reduction, mixed infections accounted for $4.79 \%$ with $47.22 \%$ reduction. With the Kruskal-Wallis test, a significant difference in the distribution of cases was recorded for Plasmodium species $(H=12.87, p=0.016)$. As for $P$. malariae, only three cases of imported origin were reported sporadically, representing $0.08 \%$ of the total.

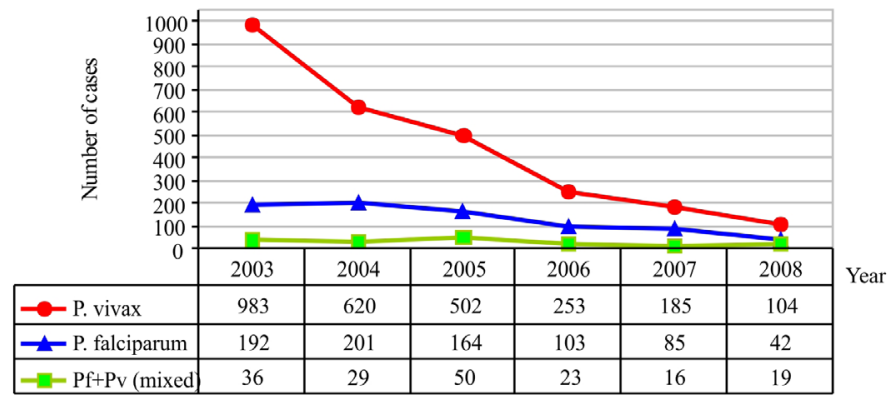

Fig. 2 - Annual distribution of malaria cases recorded in Tocantins, in the period 2003 to 2008, according to the species of Plasmodium. $(\mathrm{H}=12,87 ; p=0.016)$

Unlike what may be observed in the frequency of cases by species, the percentage of reduction did not follow the same pattern. The rate of positive smears for P. falciparum (SPfR) ranged from $15.85 \%$ in 2003 to $29.51 \%$ in 2007 , representing an increase of $86.18 \%$, but the last series took the opposite direction and diminished by $13.76 \%$. The mixed malaria index showed a similar range from $2.97 \%$ in 2003 to $11.52 \%$ in 2008 . In the meantime, the rate for $P$. vivax slides (SPvR) has decreased from $81.17 \%$ in 2003 to $63.03 \%$ in 2008, which represents a reduction of $22.35 \%$. Thus, the ratio of $P$. falciparum/P. vivax which was 0.19 P. falciparum positive slides for each slide positive for $P$. vivax, in 2003, doubled to $0.44 P$. falciparum slides for each slide for $P$. vivax, in 2007 (Table 2).

Table 2

Distribution of the indices related to the occurrence of malaria reported in Tocantins, in the period 2003 to 2008

\begin{tabular}{lccccccc}
\hline Year & API $(\mathrm{mil})$ & ABER $(\%)$ & SPR $(\%)$ & SPfR $(\%)$ & SPvR $(\%)$ & SR(Pf+Pv) & F/V \\
\hline 2003 & 0,98 & 0.38 & 25.53 & 15.85 & 81.17 & 2,97 & 0,19 \\
2004 & 0,67 & 0.36 & 18.58 & 23.65 & 72.94 & 3,41 & 0,32 \\
2005 & 0,55 & 0.29 & 19.08 & 22.87 & 70.01 & 6,97 \\
2006 & 0,28 & 0.19 & 14.56 & 27.18 & 66.75 & 6,07 \\
2007 & 0,23 & 0.16 & 14.21 & 29.51 & 64.24 & 5,56 & 0,32 \\
2008 & 0,13 & 0.10 & 12.79 & 25.45 & 63.03 & 0,44 & 11,52 \\
\hline
\end{tabular}

API - Annual Parasite Index; ABER - Annual Blood Examination Rate; SPR - Slide Positive Rate; SPfR - Slide Plasmodium falciparum Rate; SPvR - Slide Plasmodium vivax Rate, $\mathrm{SR}(\mathrm{Pf}+\mathrm{Pv})$ - Rate of Slides by Plasmodium falciparum + Plasmodium vivax; F/V - Ratio between Plasmodium falciparum/Plasmodium vivax 
PARISE, E.V.; ARAÚJO, G.C.; CASTRO, J.G.D. \& BERDARRAIN, F.P. - Epidemiological profile of malaria in the State of Tocantins, Brazil, from 2003 to 2008. Rev. Inst. Med. Trop. Sao Paulo, 53(3): 141-7, 2011.

Regarding the risk of illness, there was a sharp decline in the study period. In 2003, the Annual Parasite Index (API) recorded 0.98 cases per 1,000 inhabitants and rose to 0.13 cases per 1,000 inhabitants in 2008 , which is a decrease of $86.73 \%$. The Annual Blood Examination Rate (ABER) also showed a gradual decrease in the percentage, from $0.38 \%$ in 2003 to $0.10 \%$ in 2008 and a total reduction of $73.68 \%$ in the period.

Observing the change in the ABER and the API, it was verified that there was a continuous decline in the Slides Positive Rate (SPR) except for the year 2005, when there was an increase of $0.5 \%$ over 2004, yet at the end of the series the decrease reached $49.90 \%$.

Regarding gender, malaria struck both sexes, with predominance in males $(76.95 \%)$ over females $(23.05 \%)$, showing a constant profile in the distribution over the years. In the Mann-Whitney test a significant difference with respect to gender ( $\mathrm{U}=4.0, p=0.02)$ was detected. This behavior related to males was observed in both classifications, autochthonous and imported, but in the latter, the percentage was evident, bringing together $80.65 \%$ of the cases. In 2005, when a rise in the SPR (Table 2) was found, a rise in the proportion of male imported cases was also noticed. The same increase in the proportion of this genre was repeated in 2008, when the variation of reduction of malaria became evident (Table 1), and over $90 \%$ of the cases were imported (Fig. 1).

Regarding the age, there was a predominance of males in all age groups (Fig. 3). The highest frequency was among the individuals in the economically active age group of 15 to 49 years old (73.41\%), with an even more significant rate for the 20 to 49 years old group (62.13\%). Analyzing the individuals in this latter age group, an expressive percentage of men over women is noticed, with $80.29 \%$ of cases. It was also observed that the highest peak in the frequency of cases occurred in the age group 20-29 years; however, the highest average of the API is in the 30 to 39 years old group $(0.73 / 1,000$ inhab.) followed by the 20 to 29 years old group $(0.70 / 1,000$ inhab.) and, subsequently, in individuals between 40 to 49 years old $(0.59 / 1,000$ inhab.).

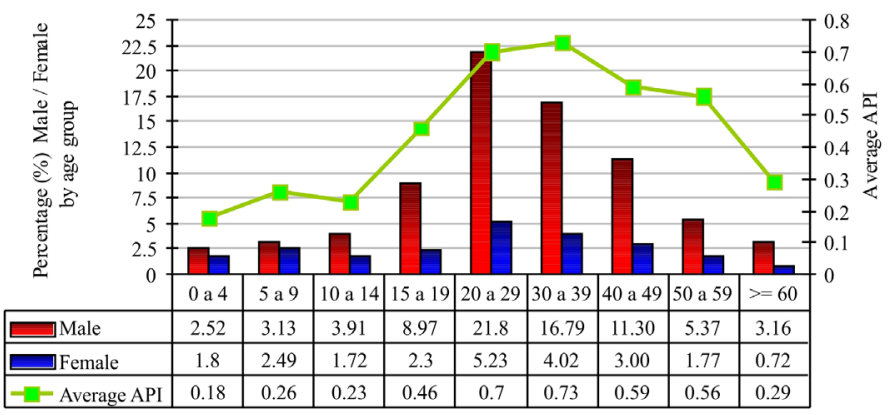

Fig. 3 - Percentage of malaria cases recorded in Tocantins, in the period 2003 to 2008, by gender and average Annual Parasite Index (API), by age group.

In this study, the low performance regarding the diagnosis and treatment was explained. The average of the six years showed that in $74.38 \%$ of the cases treatment was started within 48 hours of first symptoms. Moreover, after the suspicion of a case, the deadline for starting the treatment has been effective, on average $90.79 \%$ of the cases started treatment within 24 hours of collection of the blood sample. The rate of hospitalization increased from $21 \%$ in 2003 to $35.36 \%$ in 2006, showing a fall in 2007 , with $22.22 \%$ and again increased in 2008 , with
$26.67 \%$. The mortality coefficient, which was $8.3 / 10,000$ inhabitants in 2003 , rose to $35.3 / 10,000$ in 2004, 27.9/10,000 in 2005 and disappeared in 2006. In absolute numbers these coefficients represent only one, three and two deaths respectively.

Regarding the origin of imported cases $89.97 \%$ come from states that are part of the Amazon, especially the state of Pará, which borders Tocantins and $8.72 \%$ are coming from two neighboring countries - Guiana and Suriname; left only $1.31 \%$ of the cases arising from other states of Brazil and six other countries (Table 3).

Table 3

Distribution of malaria cases recorded in Tocantins, in the period 2003 to 2008, according State or country of origin

\begin{tabular}{|c|c|c|c|c|}
\hline & State/Coutry of origin & $\begin{array}{c}\text { Number of } \\
\text { cases }\end{array}$ & $\%$ & $\begin{array}{c}\% \\
\text { accumulated }\end{array}$ \\
\hline \multirow{7}{*}{ 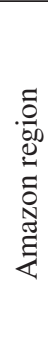 } & Amazonas & 15 & 0.63 & \\
\hline & Amapá & 19 & 0.80 & \\
\hline & Maranhão & 26 & 1.10 & \\
\hline & Mato Grosso & 14 & 0.59 & \\
\hline & Pará & 2,030 & 85.55 & \\
\hline & Rondônia & 27 & 1.14 & \\
\hline & Roraima & 04 & 0.17 & 89.97 \\
\hline \multirow{5}{*}{ 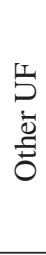 } & Bahia & 02 & 0.08 & \\
\hline & Espírito Santo & 01 & 0.04 & \\
\hline & Goiás & 01 & 0.04 & \\
\hline & Minas Gerais & 02 & 0.08 & \\
\hline & Paraíba & 02 & 0.08 & \\
\hline \multirow{9}{*}{ 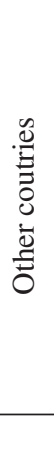 } & South Africa & 02 & 0.08 & \\
\hline & Angola & 04 & 0.17 & \\
\hline & USA & 01 & 0.04 & \\
\hline & France & 02 & 0.08 & \\
\hline & Guiana & 09 & 0.38 & \\
\hline & Venezuela & 05 & 0.21 & 1.31 \\
\hline & French Guiana & 176 & 7.42 & \\
\hline & Suriname & 31 & 1.31 & 8.72 \\
\hline & Total & 2,373 & & \\
\hline
\end{tabular}

\section{DISCUSSION}

The results showed that malaria occurred in all years and varied considerably, according to the reduction of tested samples ${ }^{9}$. As was observed previously in the Amazon region ${ }^{10,24}$, in this study there was a year in which the examined slides did not show any relation to the percentage of positive samples and this provoked the lowest index in the variation of reduction of cases of all series.

MARCHESINI et al. ${ }^{19}$ claim that a growing region tends to have 
more people being attracted to the area and therefore being exposed more intensively to the vector during the preparation of the land for housing and/or planting. In this study the frequency of positive cases showed no significant association with the demographic growth of the population coinciding with the findings of CHAVES \& RODRIGUES ${ }^{10}$. MARQUES \& GUTIERREZ ${ }^{20}$ state that there are several factors from different origins that interact for malaria transmission, including biological, ecological, socio-cultural, political and economical factors. The decreasing number of cases in Tocantins is possibly related to the intensification of control measures, such as: increased action of municipalities in the implementation of control measures, increased investment by the three spheres of government, increasing number of laboratories, insertion of control actions against malaria in healthcare programs and strengthening of treatment units ${ }^{24}$.

In this study, in the same ratio as the reduction of the overall cases there was a reduction in the number of autochthonous and imported cases, and consequently, a decreased number of municipalities where transmission was observed. Most cases are imported, and this allowed the observation that in Tocantins malaria behaves differently from other states of the Amazon, where most of cases are autochthonous. BARATA ${ }^{5}$, in his studies, reported that the proportion of malaria cases related to the introduction of imported cases varies directly with the existing surveillance system. Thus, the delay in detection of imported cases may provide outbreaks settings with relatively large proportions for the region. In Tocantins, although the number of municipalities have significantly reduced transmission, it is important to remain vigilant, because the State is part of the Amazon and has favorable characteristics for the development of the vector. In addition, the State constantly receives active carriers of the parasite, which determines the vulnerability and receptivity to worse cases.

With respect to the species of Plasmodium, a reduction of infections was observed in the three forms of malaria together with a significant difference in the annual distribution of cases by species. Considering that $65.73 \%$ of the reported cases in Tocantins are imported, this difference follows the pattern recorded in the Brazilian Amazon and is possibly related to the source of infection frequented by patients. In Brazil, $P$. falciparum predominated with more than 50\% of the cases from 1966 to 1973 and from 1984 to 1988 , which is attributed to the accelerated migration, expansion of mining activities, deforestation and settlement projects $^{12,20,33}$. P. vivax began to predominate after 1988, starting from $48.6 \%$ to over $83.7 \%$ nowadays ${ }^{26}$.

In Tocantins, the reduction in the number of malaria cases, with predominance of infections caused by $P$. vivax has been occurring since 1993, just as infection by $P$. falciparum has been reducing. That year, the index of this species represented $46.3 \%$ and went down to $20.9 \%$ in $2002^{22}$. During the period of the study, the $P$. vivax decreased $22.35 \%$, while the $P$. falciparum ranged upward ${ }^{24,32}$ in every year except in 2008, totalizing an increase of $60.57 \%$, possibly attributed to the existence of strains resistant to commonly used drugs ${ }^{36}$. The $13.76 \%$ decrease seen in 2008 is possibly related to the adoption of the new treatment plan of anti-malarial drugs adopted by the Ministry of $\mathrm{Health}^{24}$, for this species control.

Another probable cause of increase in the proportion of $P$. falciparum may be the migration flow and the proximity with settlement, as described
BARBIERI $^{7}$ and SILVEIRA \& REZENDE ${ }^{33}$. One of the indicators is that $70.39 \%$ of the cases of Plasmodium refer to imported cases and the other is that, in years when the rates were higher (2006 and 2007) the preceding cases occurred in a larger number of families settled by projects of the Agrarian Reform (2005 and 2006) ${ }^{16}$.

The Ministry of Health emphasizes that the resistance to drugs, the delay in diagnosis and treatment and the weakness of the epidemiological surveillance, are factors that contribute in the frequency of malaria ${ }^{24}$. The treatment, considered as a key measure to block the disease, must involve the breaking of the Plasmodium life cycle by interfering in the life cycle of the Anopheles mosquito, or the cycle of human disease or both $^{7}$. Therefore, in non-endemic areas, medical care, epidemiological surveillance, entomological and actions of health education are priority strategies to lessen the severity of cases and prevent spots with transmission from establishing ${ }^{1}$.

The increase in the percentage of $P$. falciparum infections observed in this study may be directly related to the delay in implementing the necessary actions to stop outbreaks of transmission ${ }^{35}$, since $74.38 \%$ of cases started treatment after 48 hours of onset of first symptoms.

The calculation of the Annual Parasite Index (API) indicates that Tocantins is part of the low risk classification, where the API varies between 0.1 and 9.9 cases per thousand inhabitants, different from the average found in the Amazon Region, classified as medium risk, and the states of Acre, Amazonas and Roraima, classified as high risk ${ }^{24}$.

The Annual Blood Examination Rate (ABER) did not reach the ideal $10 \%$ for a good detection of malaria ${ }^{11}$ but it followed the change in the Annual Parasite Index (API) ${ }^{33}$, showing a declining trend throughout the series. In this case, it must be taken into consideration that the calculation of the ABER was obtained by computing the entire population of the State, directly and indirectly protected, and not only in one region under threat ${ }^{11}$.

The reduction in the ABER represented the demand of malaria cases in the State and, consequently, there was a reduction in the Slides Positive Rate (SPR), corresponding to the expected course, however, it is different from the results reported in the Brazilian Amazon ${ }^{33}$ and in Colombia $^{37}$. In this, VALERO-BERNAL ${ }^{37}$ found that the reduction in the ABER resulted in a considerable increase in the SPR and the API, showing evident resurgence of the pathology with weak possibilities of control, possibly enhanced by a reduced accessibility and low coverage of the healthcare system.

This sharp decline in the ABER, API and SPR means a reduction in the transmission levels in Tocantins, which could be related to improvements in the structuring of healthcare services, implemented since 1999 with the beginning of the decentralization of control actions of vector diseases, from FUNASA to the states.

Regarding gender, malaria focused more frequently on males ${ }^{1,21,34,39}$, and aged 15 to 49 years old o, $^{6,25,30,35}$, possibly attributed to the mobility, type of occupation and/or environment in which they reside. This increased participation of males and working age individuals expresses the relocation of labor in the search for employment in areas of greatest risk of transmission, where activities related to agriculture 


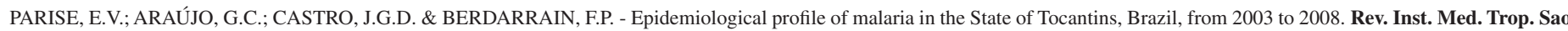
Paulo, 53(3): 141-7, 2011

usually prevail, like livestock, hunting/fishing, mining and agricultural exploitation ${ }^{4,7,14,24,28,31}$.

Considering that malaria occurs most often outside home, it is clear that individuals over 14 are much more exposed to environments propitious to infected vectors, as they start to enter the productive chain and respond to the social phenomenon of work conditions and begin a process of family independence. In this study, women and children under 10 represent the smaller proportion of cases, since they travel less, tend to stay longer inside home, and can use nets and other forms of prevention against exposure to the vector, keeping themselves more protected ${ }^{21,39}$.

According to what has already been noted, the speed in diagnosis and treatment is essential to interrupting the transmission chain and to prevent the development to more serious forms of the disease ${ }^{24}$. However, in the study period, the low diagnosis and treatment performance was clear. Only $22.12 \%$ were under treatment within 48 hours from the first symptoms. From an epidemiological point of view, it represents a longer period of circulating parasitemia in patients and therefore a greater possibility of Anopheles infection with increasing transmission levels ${ }^{38}$. This fact may have influenced the proportion of $P$. falciparum infections and also in the percentage of hospitalization, even though it became evident that most of these infections are of imported origin.

SILVEIRA \& REZENDE ${ }^{33}$ point out that the variation in admission rates for malaria treatment tends to reproduce closely the variation in the incidence of cases caused by P. falciparum. In Tocantins, for the period 2003 to 2008, the index of hospital admission did not follow the steady decrease presented by the SPR and the API, but the increases followed the SPfR, except in 2007. This may be related to the low number of cases, when the health professionals start to become unconcerned about the disease, not taking into account its explosive potential, and when they realize the patient has severe symptoms, making it necessary special care. When analyzing the mortality rate, it was found that this indicator is under control since, in absolute numbers, there have only been a few deaths and they have stopped occurring since 2006.

When analyzing the origin of cases, it was found that the majority came from the Amazon region and the neighboring countries, French Guiana and Suriname, which are endemic areas for malaria. These regions offer various activities related to land, mining, road construction and agricultural exploitation, these being attractive to the self-employed. By exposing themselves to the source of infection without the required protection, workers get infected and after some time, they return to their families, carrying the parasite of malaria in the bloodstream, resulting in imported cases in Tocantins.

When analyzing the delay in initial treatment for Tocantins, it is probably related to the effort of the infected individuals to keep on working away from their hometown as long as possible until the situation gets unbearable and they return home for treatment. Faced with this situation, there is a need to strengthen the basic healthcare services for treating patients suffering from malaria, especially concerning to diagnosis and treatment, as well as improving health education actions in order to guide the population to seek treatment as early as possible, because, although there was an annual reduction in the number of cases, the State is vulnerable and open to worse events, according to the constant population movements.
Regarding the deadline for starting treatment, the rates have proven to be inadequate, and the situation is different for disease control. Generally, it was clear that the persistent decline of autochthonous and imported cases signaled that the State is leaving the endemic area of the disease and is entering the area with residual transmission. Nevertheless, it is still important to maintain effective surveillance measures in the entire State in order to preserve the unaffected areas and to identify early cases that emerge, to avoid localized outbreaks.

\section{RESUMO}

\section{Perfil epidemiológico da malária no Estado do Tocantins, Brasil, no período 2003 a 2008}

Este estudo descreve o perfil epidemiológico da malária no Estado do Tocantins, no período 2003 a 2008, investiga a associação entre a frequência da malária e o crescimento populacional, classifica os casos por autóctone e importada, relaciona os índices da doença e analisa a distribuição dos casos por espécie de Plasmodium, faixa etária e gênero. $\mathrm{O}$ estudo retrospectivo baseou-se em dados secundários, armazenados no SIVEP-malária e analisados através dos Softwares Epi-Info 3.5.1. e Bioestat 5.0. Foram investigadas 19.004 amostras para malária, sendo $19 \%$ positivas; $73,32 \%$ por Plasmodium vivax, $21,80 \%$ por Plasmodium falciparum, $4,79 \%$ por infecções mistas e $0,08 \%$ por Plasmodium malariae. Os indivíduos masculinos representaram 76,95\% e predominaram em todos os anos e faixas etárias, principalmente naqueles de 15 a 49 anos. Do total de casos, 34,27\% tiveram origem autóctone e $65,73 \%$ importado $\left(\chi^{2}=356,8 ; p=0,0001\right)$. A frequência da malária reduziu de forma significativa durante toda série histórica $\left(\mathrm{r}_{\mathrm{p}}=0,96 ; p=\right.$ $0,002)$ e, concomitantemente, reduziram os municípios com transmissão autóctone. Constatou-se que a malária é predominantemente importada, relacionada às atividades de campo, que confirma a necessidade de manter medidas efetivas de vigilância em todo Estado e aprimorar ações educativas no sentido de orientar a população na busca pelo atendimento precoce.

\section{ACKNOWLEDGEMENTS}

We thank the Science and Technology Office of the State of Tocantins, the program of support for Higher Education Research, for the financial support given to the research and to the team of the State Malaria Center, for contributing with the information.

\section{REFERENCES}

1. Alves MJCP, Mayo RC, Donalisio MR. História, epidemiologia e controle da malária na região de Campinas, Estado de São Paulo, Brasil, 1980 a 2000. Rev Soc Bras Med Trop. 2004; 37:41-5.

2. Arruda ME, Zimmerman RH, Souza RM, Oliveira-Ferreira J. Prevalence and level of antibodies to the circumsporozoite protein of human malaria parasites in five states of the Amazon region of Brazil. Mem Inst Oswaldo Cruz. 2007;102:367-71.

3. Atanaka-Santos M, Czeresnia D, Souza-Santos R, Oliveira RM. Comportamento epidemiológico da malária no Estado de Mato Grosso, 1980-2003. Rev Soc Bras Med Trop. 2006; 39:187-92.

4. Atanaka-Santos M, Souza-Santos R, Czeresnia D. Spatial analysis for stratification of priority malaria control areas, Mato Grosso State, Brazil. Cad Saúde Pública. 2007;23:1099-112. 

Paulo, 53(3): 141-7, 2011.

5. Barata RCB. Malária no Brasil: panorama epidemiológico na última década. Cad Saúde Pública. 1995;11:128-36.

6. Barbieri AF. Uso antrópico da terra e malária no norte de Mato Grosso, 1992 a 1995. [Dissertação]. Belo Horizonte: Universidade Federal de Minas Gerais; 2000.

7. Barbieri AF. Uso do solo e prevalência de malária em uma região da Amazônia Brasileira. Cad Geogr. 2005;15:9-30.

8. Barbosa WB. Levantamento epidemiológico de malária na cidade de Manaus em 2005. Rev Ci Med Biol. 2008;7:156-62.

9. Bértoli M, Moitinho MLR. Malária no Estado do Paraná, Brasil. Rev Soc Bras Med Trop. 2001;34:43-7.

10. Chaves SS, Rodrigues LC. An initial examination of the epidemiology of malaria in the state of Roraima, in the Brazilian Amazon Basin. Rev Inst Med Trop Sao Paulo. 2000;42:269-75

11. Corrêa RR, Alves UP. Informes sobre o programa de erradicação da malária do Estado de São Paulo. Rev Saúde Pública. 1969;3:93-104.

12. Coura JR, Suárez-Mutis M, Ladeia-Andrade S. A new challenge for malaria control in Brazil: asymptomatic Plasmodium infection: a review. Mem Inst Oswaldo Cruz. 2006;101:229-37.

13. Dias RC. Uma contribuição ao estudo da malária no Estado de Roraima e sua associação com a precipitação pluviométrica no período de 1985 a 1996. [Tese]. Rio de Janeiro: Escola Nacional de Saúde Pública, Fundação Osvaldo Cruz; 2003.

14. Harris AF, Matias-Arnéz A, Hill N. Biting time of Anopheles darlingi in the Bolivian Amazon and implications for control of malaria. Trans R Soc Trop Med Hyg. 2006;100:45-7.

15. Instituto Brasileiro de Geografia e Estatística (IBGE). Unidades Territoriais de cada unidade da Federação - Estado do Tocantins. Available from: http://www.sidra.ibge. gov.br. Accessed May 30, 2009.

16. Instituto Nacional de Colonização e Reforma Agrária (INCRA). Dados sobre Projetos de assentamentos no Tocantins no período de 1987 a 2008, Palmas, Tocantins, 2009.

17. Instituto de Desenvolvimento Humano Sustentável da PUC Minas (IDHS); PNUD Brasil. OBJETIVO 6: combater o HIV/AIDS, a malária e outras doenças. In: Objetivos do Milênio. Belo Horizonte: PUC Minas; 2005. p. 76-116. Available from: http://www. virtual.pucminas.br/idhs/02_pnud/ODM_WEB/livro_4_dividido/livro4b_objetivo6. pdf. Accessed June 05, 2008.

18. Lou J, Lucas R, Grau GE. Pathogenesis of cerebral malaria: recent experimental data and possible applications for humans. Clin Microbiol Rev. 2001;14:810-20.

19. Marchesini PB, Spencer B, Lima MC. Distribuição espacial da malária no município de Machadinho/RO, 1994. In: Encontro na Associação Brasileira de Estudos Populacionais, 10., 1996, Caxambu. Anais. Belo Horizonte: ABEP; 1996. p. 2427-42.

20. Marques AC, Gutierrez HC. Combate à malária no Brasil: evolução, situação atual e perspectivas. Rev Soc Bras Med Trop. 1994; 27(Suppl 3):91-108.

21. Marques GRAM, Condino MLF, Serpa LLN, Cursino TVM. Aspectos epidemiológicos de malária autóctone na mata atlântica, litoral norte, Estado de São Paulo, 1985-2006. Rev Soc Bras Med Trop. 2008;41:386-9.

22. Ministério da Saúde. Secretaria de Vigilância em Saúde. Coordenação-Geral do Programa Nacional de Controle da Malária. Plano de Intensificação das Ações do Controle da Malária na Amazônia Legal - PIACM: período julho de 2000 a dezembro de 2002. 2a ed. rev. Brasília: Ministério da Saúde; 2004.
23. Ministério da Saúde. Secretaria de Vigilância em Saúde. Situação epidemiológica da malária no Brasil, 2006. Brasília: Ministério da Saúde; 2006.

24. Ministério da Saúde. Secretaria de Vigilância em Saúde. Situação epidemiológica da malária no Brasil, 2008. Brasília: Ministério da Saúde; 2008

25. Mishra SK, Mohanty S. Clinical presentations of severe and complicated malaria in India. J Indian Acad Clin Med. 2001;2:125-7.

26. Oliveira-Ferreira J, Lacerda MVG, Brasil P, Ladislau JLB, Tauil PL, Daniel-Ribeiro CT. Malaria in Brazil: an overview. Malar J. 2010;9:115.

27. Organização Pan-Americana da Saúde (OPAS). A malária e as metas de desenvolvimento internacionalmente acordadas, inclusive as constantes da declaração do milênio. CD46/17. julho 2005. Available from: http://www.paho.org/portuguese/ gov/cd/cd 46-17-p.pdf. Accessed Nov 08, 2007.

28. Rezende K, Lima SC, Lemos JC. Vetores da malária na área de construção das usinas hidrelétricas Capim Branco I e Capim Branco II, na bacia do rio Araguaia no município de Uberlândia, Minas Gerais - Brasil. Horizonte Ci. 2007;1:1-20. Available from: http://www.horizontecientifico. propp.ufu.br. Accessed Oct 29, 2007.

29. Rede Interagencial de Informações para a Saúde (RIPSA), 1997. Qualificação de indicadores do IDB - Malária: Incidência Parasitária Anual (Índice de Positividade de Malária). Available from: http://tabnet.datasus.gov.br/cgi/ idb1997/morb/fqd0205. htm. Accessed Jan 22, 2009.

30. Salcedo JMV, Camargo EP, Krieger H, Silva LHP, Camargo LMA. Malaria control in an agro-industrial settlement of Rondônia (Western Amazon Region, Brazil). Mem Inst Oswaldo Cruz. 2000;95:139-45.

31. Service MW. Agricultural development and arthropod-borne diseases: a review. Rev Saúde Pública. 1991;25:165-78.

32. Silva AR, Fernandes JMC, Rodrigues TA, Santos HJ, Cavalheiro NNM, Guimarães MC, et al. Controle da malária no Estado do Maranhão. Rev Soc Bras Med Trop. 2009;42:318-24.

33. Silveira AC, Rezende DF. Avaliação da estratégia global de controle integrado da malária no Brasil. Brasília: Organização Pan-Americana de Saúde; 2001.

34. Souza-Santos R, Oliveira MVG, Escobar AL, Santos RV, Coimbra-Jr CEA. Spatial heterogeneity of malaria in Indian reserves of Southwestern Amazônia, Brazil. Int J Health Geogr. 2008;7:1-10.

35. Suárez-Mutis MC, Coura JR. Mudanças no padrão epidemiológico da malária em área rural do médio Rio Negro, Amazônia brasileira: análise retrospectiva. Cad Saúde Pública. 2007;23:795-804.

36. Tauil P, Deane L, Sabroza P, Ribeiro C. A malária no Brasil. Cad Saúde Pública. 1985;1:71-111.

37. Valero-Bernal MV. Malaria in Colombia: retrospective glance during the past 40 years. Rev Salud Pública (Bogotá). 2006;8:141-9.

38. Wanderley DMV, Andrade JCR, Meneguetti LC, Chinelatto MJ, Dutra AP. Malária no Estado de São Paulo, Brasil, 1980 a 1983. Rev Saúde Pública. 1985;19:28-36.

39. Yeshiwondim AK, Gopal S, Hailemariam AT, Dengela DO, Patel HP. Spatial analysis of malaria incidence at the village level in areas with unstable transmission in Ethiopia. Int J Health Geogr. 2009;8:5.

Received: 23 October 2010

Accepted: 30 March 2011 


\section{Revista do Instituto de Medicina Tropical de São Paulo on line.}

Publications from 1990 to the present data are now available on:

http://www.scielo.br/rimtsp

PAST ISSUES 1959-1989 (PDF)

www.imt.usp.br/portal/

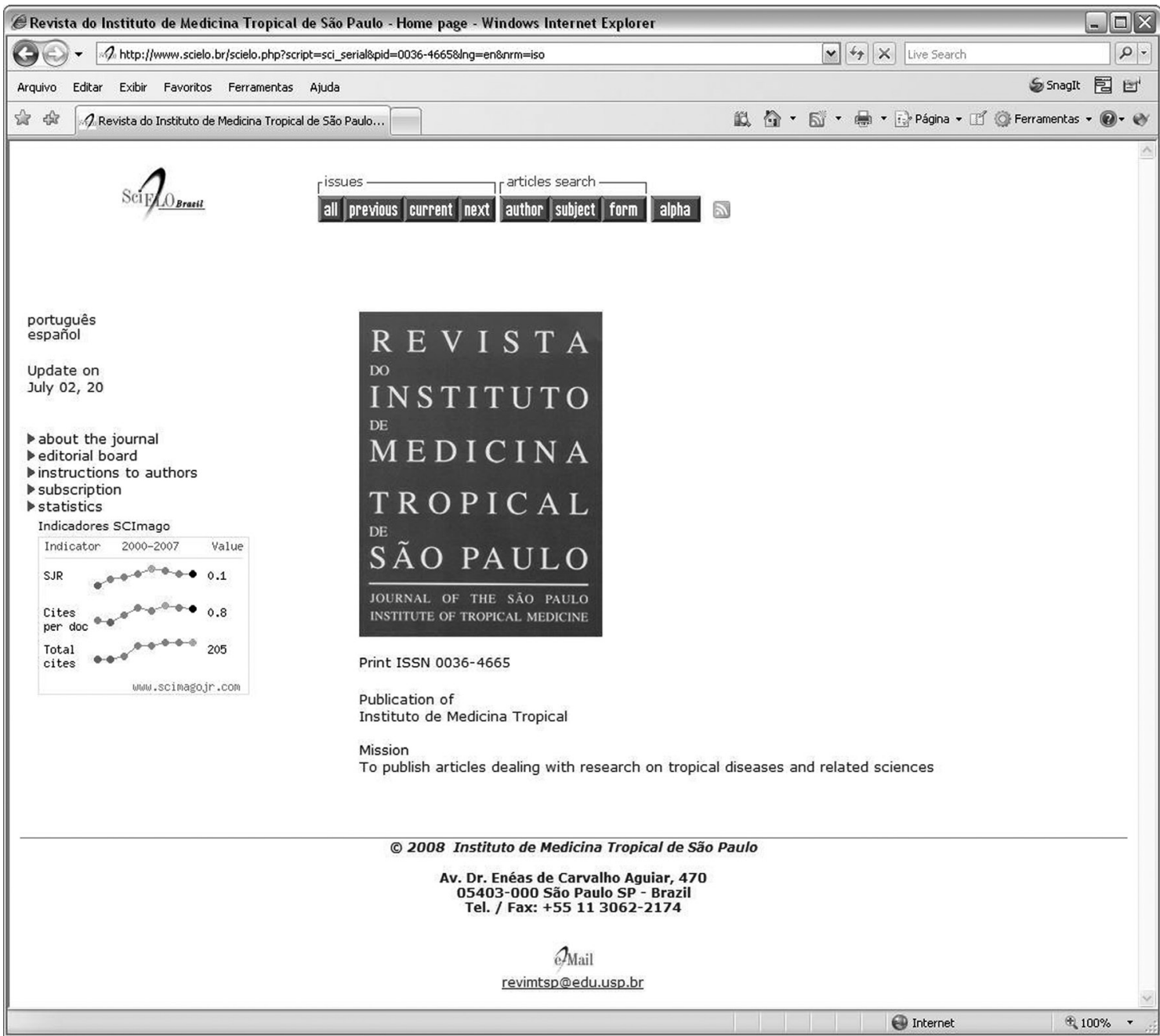

SciELO - The Scientific Electronic Library OnLine - SciELO is an electronic virtual covering a selected collection of Brazilian scientific journals.

The library is an integral part of a project being developed by FAPESP - Fundação de Amparo à Pesquisa do Estado de São Paulo, in partnership with BIREME - the Latin American and Caribbean Center on Health Sciences Information.

SciELO interface provides access to its serials collection via an alphabetic list of titles or a subject index or a search by word of serial titles, publisher names, city of publication and subject.

The interface also provides access to the full text of articles via author index or subject index or a search form on article elements such as author names, words from title, subject and words from full text.

FAPESP/BIREME Project on Scientific Electronic Publications Latin American and Caribbean Center on Health Sciences Information

Rua Botucatu 862 - 04023-901 São Paulo, SP - Brazil

Tel. (011) 5576-9863

scielo@bireme.br 